\title{
Transformational-Transactional Leadership and Organizational Cynicism Perception: Physical Education and Sport Teachers Sample
}

\author{
Yeliz Eratı Şirin*, Özge Aydın, Fatma Pervin Bilir \\ Physical Education and Sports Department, Çukurova University, Turkey
}

Copyright $\bigcirc 2018$ by authors, all rights reserved. Authors agree that this article remains permanently open access under the terms of the Creative Commons Attribution License 4.0 International License

\begin{abstract}
The purpose of this study was to find out the transformational and transactional leadership and organizational cynicism perceptions of physical education and sports teachers. The sample of the study consists of 70 physical education teachers chosen randomly who were working in schools of Turkey during the 2017-2018 Academic year. Personal information form, transformational and transactional leadership scale and organizational cynicism scale were used in the study. Descriptive statistics were used to analyse the data obtained from the study. Kurtosis and Skewness values were found to show whether the variables of the study were normally distributed and t-test was used for paired comparisons, while Anova test was used for the comparison of more than two independent groups. According to the results of the study physical education teachers were found to have higher perceptions of transformational leadership when compared with transactional leadership and they were found to have moderate levels of organizational cynicism. While significant difference was found between transformational and transactional leadership styles and the variable of gender; no significant difference was found between gender and organizational cynicism sub-dimensions. Another result of the study was that no significant difference was found between the variables of type of school teachers worked in, age and school graduated from and organizational cynicism sub dimensions, transformational and transactional leadership styles. Also significant difference was found between the variable of teachers' professional seniority and cognitive dimension, affective dimension and behavioural dimension.
\end{abstract}

Keywords Organizational Cynicism, Transformational Leadership, Transactional Leadership, Physical Education

\section{Introduction}

In the increasingly dynamic world of our day, organizations are faced with some changes that they feel the need to apply in their strategies, structures, operation processes and institution cultures. Therefore, the influence of change factors draws the attention not only outside the institution but also within the institution. A great amount of effort and resources are required to understand the resistance to the institution, organization, manager or employer and to minimize this resistance. The essential point of this resistance is the concept of cynicism, which has increasingly come to the forefront recently [1]. Researches about the concept of cynicism started in businesses first. At the beginning of 2000s, organizational cynicism began to be reflected in educational institutions $[2$, 3]. This situation emerged as a result of organizational structures of educational institutions including bureaucratic characteristics, achieving institutional success, realizing new quality and efficiency centered practices and also as a result of the attitudes of employees towards the institution [4]. As in the functioning of all institutions, the presence of successful, efficient, innovative and entrepreneur leaders who are sensitive to the needs and problems of the society, who can update according to the needs of the time, who attain goals with a team spirit together with all the workers, mainly teachers, who are charismatic, well-informed, virtuous, visionary, entrepreneur, principled and hardworking in creating an understanding that can organize motivated individuals beyond expectation in order to realize the goals of the institution is vitally important in educational institutions [5].

Values and leadership perceptions of managers is important in the development and also in preventing the development of cynicism in organizations because leadership is an important factor in fighting problems such as insecurity, estrangement and decrease in organizational 
commitment as a result of negative thoughts and feelings of employees towards management and the organization. For this reason, discussing the effects of managers' leadership styles on organizational cynicism is useful in terms of both understanding some factors that cause organizational cynicism and also finding out the approaches to follow in fighting organizational cynicism [6].

This study examines how leadership behaviours in schools are perceived by physical education teachers and the levels of organizational cynicism in schools. Within this context, first the concepts of transformational and transactional leadership styles and organizational cynicism were explained and then it was found how leadership styles and organizational cynicism were perceived in terms of the demographic characteristics of physical education teachers working in schools.

Literature review conducted showed studies related with the leadership and organizational cynicism perceptions of teachers in general, while no studies were found which were focused on branch teachers. For this reason, teachers of physical education and sports, who are one of the most important factors in exploring and developing sport and athletes, were chosen in this study. Thus, it can be said that the present study is original. It is thought that the results of this study will contribute to existing literature on these leadership styles (transformational and transactional) and be useful in choosing, training and developing leaders in educational institutions. At the same time, the study will give information about the level of organizational cynicism levels in educational institutions.

\section{Leadership Concept}

Today, it is accepted in studies about leadership that leadership is the process of influencing people to realize specific goals by using methods of motivation rather than power or authority $[7,8]$. Leadership is the sum of all the knowledge and abilities to gather a group of people around specific goals and to motivate them to realize these goals [9]. According to another definition, leadership is the process of a person's influencing and directing other people's behaviors and activities through volunteerism in order to determine the specific aims of a person or a group and to realize these aims under specific terms [10]. A great number of approaches have been developed about leadership so far. Theoreticians working on leadership approaches have first focused on the innate personal characteristics of a leader, that is what a leader is, and have put forward the approach of characteristics. Later, because of the lacks in the approach of characteristic behavioral approach, which puts forward that the leader's behaviors are effective in explaining the process of leadership and which focuses on "what and how" a leader does, has come into being. Since behavioral approach ignored the role played by situational factors, contingency approach, which advocates that the most suitable leadership behavior can change according to conditions and situations, has appeared [11]. When the changes in the field of management revealed that the traditional approaches in leadership styles were not sufficient, new leadership approaches were developed. Developments and new concepts in the field of management and organization have caused the emergence of new approaches in the field of leadership and especially after 1978 new distinctions were made based on German sociologist Max Weber's charismatic leadership theory and classifications were made under the names of transactional leader, the leadership style of which depended more on traditions and the past, and transformational leader, the leadership style of which was open to future, innovation and change. In other words, leaders who associated the past with today were called transactional leaders, while those who associated today with the future were called transformational leaders [12].

\section{Structure and Concept of Transformational and Transactional Leadership}

As a result of the researches they conducted, Burns and Bass stated that it would be more suitable to assess the concept of leadership under two main titles as transformational and transactional leadership [13]. Transformational Leadership

It is the kind of leadership in which leaders build a connection between themselves and followers-workers, influence employees, become a role model to them, sincerely encourage them to work beyond their performance, try to realize the targets of the organization within cooperation and unity by acting with team spirit, follow change and development, keep the organization energetic within the competition environment and keep the organization close to success all the time [2].

In the first step of transformational leadership, the leader ensures juniors to perceive the results of their job more important and valuable. In the second step, transformational leaders encourage juniors to surpass themselves and to increase the effort they spend for the group and the environment. In the last step, it is accepted that the leader is effective in changing and extending the needs of juniors [14]. This step results with the transformation of both juniors and the leader [15]. Transformational leader defines the need for change, develops a vision for the future and mobilizes the commitment of his/her followers to meet the needs beyond the normally expected [5]. In other words, transformational leaders search to increase their followers' awareness by attracting them to higher ideals and moral values such as freedom, justice, peace and kindness rather than low feelings such as fear, greed, jealousy or enmity and grudge [16]. Transformative leaders accept leadership as a process which stimulates and inspires their followers and develops their own leadership skills [17]. Bass (1985) and Bass and 
Avolio (1994) classified transformative leadership in four categories [18]. These categories are (i) idealized influence (charisma): The leader, who is a perfect role model for his followers, makes correct decisions for the organization and gains the trust and respect of his followers; Intellectual Impulse, encourages a group for innovation and creativity to change their beliefs or views [19]. Individual support: Acts according to the skills, information and individual differences of his followers and enables them to be promoted to where they can to show their maximum performance [20]. Rapidly changing living conditions have necessitated transformation from old models to new ones in the structures of schools. This transformation occurs from hierarchical bureaucratic designs towards more networked and flexible designs in schools [21]. Leithwood and colleagues found that transformational leadership has a significant effect on teachers' emotions, beliefs and commitments to change Leithwood and Sun [22]; while Midthassel and Erstesvag [23] found that those schools who successfully implemented the interventions had leaders who were both transformational and transactional.

Transactional leadership is based on "conditional reward based exchange" relationship between the leader and the juniors [24]. Unlike transformational leaders, transactional leaders focus on short term physical and safety needs of juniors within the context of economic exchange model. In this sense, transactional leaders show not proactive but reactive behaviours [25]. Transactional leaders do not intervene with the existing functioning system of the organization, they motivate their workers with rewarding, they promise position, status and money to their workers for success, they are not much interested in their workers' characteristics and their entrepreneur and innovative sides, activities continue like this within the basic mission and vision of the organization [26]. In transactional leadership, which depends on mutual transaction, when the viewers do their duties, they are faced with reward and when they don't, they are faced with punishment [27]. Bass (1985) states that transactional leadership depends on three basic methods in application. These are conditional rewarding, which includes determining what needs to be done for the fulfillment of duties or the acceptance of wievers; "management with exceptions (active/passive), in which the leader watches the employees, interferes with the mistakes imediately, prevents deviating from the objectives, finds out the problematic fields and improves these [28] and "complete freedom" leadership, in which the leader is never around in the organizational environment when needed, always postpones problems and avoids making decisions [29]. Studies suggest that transactional leadership can only be exercised when the leader has power to reward and to punish, which is lacking in most public sector organizations [30].

A great number of new approaches have been suggested recently. Of these approaches, transactional and transformational leadership are leadership approaches which have been addresses and analysed intensively. Transactional leaders view leader-follower relationship as a process of "exchange" and they try to apply existing management techniques efficiently and in parallel with the rules [31]. Transformational leaders both have transactional leadership characteristics and in addition adapt a more future focused management style, give their followers the opportunity to see events with a new point of view, persuade followers to value the targets of the group more than their own personal goals, make the necessary changes and improvements in their organization and question the existing principles and make new principles so that the organization can reach superior performance level [32].

\section{Cyntcism and Organizational Cynicism}

"Cynic" is defined as someone who believes that everyone just watches for their own interests and thus accepts everyone as calculating and the thought that tries to explain this is called "cynicism". The main belief about cynicism is that the principles of justice, honesty and sincerity are sacrificed for personal interests. [33]. Andersson and Bateman (1997) defined cynicism as both a general and specific attitude characterized by disillusionment, frustration, with negative feelings toward and distrust of a person, group, ideology, social convention, or institution. [34].

The concept of cynicism is generally defined as "not believing in sincerity and good in motives and acts that motivate a person and making a habit of emphasizing this with a smile, the tendency to find fault by despising” [35]. Cynicism activates emotional factors such as anger, shame, scorning and distress; in short, strong negative feelings [36]. Cynicism is individuals' getting a despising and critical point of view as a result of negative experiences and feelings [37]. Studies about cynicism in literature. Abraham (2000) and Dean et al. (1998) stated that cynicism was grouped in five different frameworks which were, Personal cynicism [36, 38], which is an innate, unchanging characteristic and which reflects a negative understanding of individuals' behaviors; Societal cynicism [39] which is defined as the citizens of a country not trusting their state and institutions; Employee cynicism [40], which occurs as a result of doing away with the distance between employers and employees by decreasing the number of management line in the organization; organizational change cynicism [39], which is defined as the belief that individuals responsible for future changes in the organization are not equipped and hardworking and the belief in employees that the organization will be unsuccessful; and work cynicism [36] which is defined as the person-role conflict which originates from the person in general. The concept of organizational cynicism emerged with the book by Kanter and Mirvis [41] which was about 
the reasons why cynicism began to be popular in organizations and studies about organizational cynicism intensified especially in 1990s. The concept of organizational cynicism, which is based on the theories of expectations, reference, attitude, social change, emotional incidents and social motivation, is defined as "the tendency of showing despising and critical behaviors which emerge as a result of the belief that the organization lacks honesty and as a result of negative feelings towards the organization and it comprises three dimensions: (1) a belief that the organization lacks integrity; (2) negative affect toward the organization; and (3) tendency of showing critical behaviors towards the organization" [38]. Cynicism occurs due to individual or organizational features. At this point, we have the concept of organizational cynicism. Organizational cynicism is defined as an attitude consisting of cognitive (belief), affective (affect) and behavioural (behaviour) tendencies [42]. According to another definition, organizational cynicism is defined as the negative attitudes an employee develops for the organization and it is defined as a three dimensional attitude as the tendency to behave in a critical and insulting way to the organization in parallel with the belief that the organization lacks honesty and the negative feelings and beliefs about the organization [43]. In their study, Helvac1 and Çetin [43] defined organizational cynicism as a negative attitude of employees against the organization and as disbelief in the decisions of the organization, not trusting the intentions of the organization and as the belief that managers do not reflect their real characters. Based on these definitions in literature, organizational cynicism can be defined as the feeling that a person is devoid of honesty against the organization that he/she works for, not having feelings of belonging, having feelings of anger, shame and disrespect and the tendency to have despising and negative behaviours against the organization [44]. Cynic employees believe that employers serve their personal interests and that the economic prosperity of the management is put ahead of the employees' interests [45].

Organizational cynicism is a negative attitude which includes cognitive, affective and behavioural dimensions an individual develops for the organization he/she works for [43]. In that definition organizational cynicism is one's negative attitudes to his/her organization and it has three dimensions. These dimensions are: The cognitive dimension of organizational cynicism is the belief that organization lacks sincerity and reliable. The affective dimension of organizational cynicism refers to the emotional and sentimental reactions to the organization (such as, trouble, shame, anger and disrespect). The behavioural dimension of organizational cynicism refers to negative tendencies about events in the organization [46]. While organizational cynicism reduces effectiveness and productivity in organizations, it can cause material and moral losses. In this sense, factors such as decrease in organizational commitment increase in quitting work, dissatisfaction in work, alienation to work and decrease in organizational performance can be shown among organizational cynicism results $[47,48]$. A great number of different factors are observed to cause cynicism in organizations. Organizational, personal and social variables can be mentioned as variables triggering organizational cynicism, which is stated to be an organizationally harmful behavior [49]. In addition, it can be said that individuals' negative moods, their low organizational support perceptions, their negative professional experiences of having psychological difficulties and organizational policies also cause organizational cynicism [50]. Cynicism is a notable concept in recent years in the literature of educational administration. Investigating the concept of cynicism that reflects negative attitudes and working to solve it, is important for the organizations. The fact that the school principals are in a transformational approach in educational organizations causes teachers to give positive reactions [51]. When it comes to organizational considerations that many of the personal and organizational aspects of cynicism are thought to be, it is becoming a priority to prevent the emergence of cynicism in the workplace or to implement effective strategies to manage it when such a situation arises. Undoubtedly the greatest responsibility for implementing such strategies lies in the managers and leaders in the organization [52]. Organizational cynicism is variable; whose relation with leadership is a focus of research $[53,54]$.

The main purpose of this study is to find out leadership styles and organizational cynicism perceptions of school directors in terms of demographic characteristics according to teachers of physical education. Research questions are the following:

1. What are the perceptions of teachers towards school directors' leadership styles?

2. What is the level of teachers' organizational cynicism perceptions?

3. Are there differences between teachers' transformational and transactional leadership perceptions and their demographic characteristics?

4. Are there differences between teachers' organizational cynicism perceptions and their demographic characteristics?

\section{Material and Method}

This study was conducted according to descriptive screening model in order to find out physical education teachers' transformational and transactional leadership perceptions and to find out how organizational cynicism levels are shaped according to some demographic variables. The universe of the study consists of physical education teachers working in Turkey during 2017-2018 academic year. The sample consists of a total of 270 physical 
education teachers, 136 female and 124 male, who participated in the study voluntarily through random sampling method.

\subsection{Data Collection Tool}

Personal information form was used in the study to find out the demographic features of physical education teachers. The form consisted of independent variables such as gender, age, type of school the teacher worked in, professional seniority and the department graduated from.

\subsection{Organizational Cynicism Scale}

Organizational Cynicism Scale, which was developed by Dean, Brandes and Dharwadkar [55] which was adapted into Turkish by Kalağan [56], includes 5-Likert type items ( $1=$ Totally disagree, $2=$ Disagree, $3=$ Neither agree nor disagree, $4=$ Agree, $5=$ Totally agree). As a result of the reliability analysis conducted, Cronbach's alpha reliability coefficient was found as 0.94 .

\subsection{Transformational and Transactional Leadership Scale}

Multi-factor Leadership Questionnaire (MLQ) developed by Bass and Avolio [57], was used to find out leadership styles. The questionnaire has 36 items and the items are assessed with a 5-Likert type scale ranging from " $1=$ totally disagree to $5=$ totally agree". Leadership styles measured by 36 items in the questionnaire are grouped under 2 general factors and 7 sub-factors. In this study, leadership styles were not assessed in terms of sub-factors but as two general factors as transformational and transactional leadership styles. As a result of reliability analysis conducted, transformational leadership Cronbach's alpha reliability coefficient was found as 0.89 and transactional leadership Cronbach's alpha reliability coefficient was found as 0.85 . The two factors were also found to be highly reliable according to the Cronbach alpha coefficients.

\subsection{Data Analysis}

Descriptive analysis such as percentage, frequency, arithmetic mean and standard deviation were used in data analysis. Coefficient of skewness was calculated for the distribution of the results of multi-factor leadership and organizational cynicism scale and it was found that the coefficient of skewness was between -2 and +2 for both variables (transformational leadership skewness $_{\text {: }}-.57$, transactional leadership skewness $_{\text {. .81; cognitive }}$ cynicism $_{\text {skewness }}$; -.09; affective cynicism skewness; .45 ;

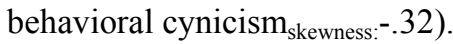

For this reason, parametric tests were used. While independent samples test was used for paired comparisons,
Anova test was used for multiple comparisons.

\section{Results}

Table 1. Participants' Demographic Characteristics

\begin{tabular}{|c|c|c|c|}
\hline \multicolumn{2}{|c|}{ Variables } & $\mathbf{N}$ & $\%$ \\
\hline \multirow{2}{*}{ Gender } & Female & 136 & 50.4 \\
\hline & Male & 134 & 49.6 \\
\hline \multirow{3}{*}{ Age } & $21-25$ & 41 & 15.2 \\
\hline & $26-30$ & 78 & 28.9 \\
\hline & 31 and older & 151 & 55.9 \\
\hline \multirow{2}{*}{ Type of School } & Secondary & 181 & 67.0 \\
\hline & High & 89 & 33.0 \\
\hline \multirow[t]{3}{*}{ Professional seniority } & $1-5$ years & 154 & 57.0 \\
\hline & $6-10$ years & 66 & 24.4 \\
\hline & $\begin{array}{c}11 \text { years and } \\
\text { higher }\end{array}$ & 50 & 27.0 \\
\hline \multirow[t]{3}{*}{ School graduated } & Teaching & 169 & 62.6 \\
\hline & Coaching & 76 & 28.1 \\
\hline & $\begin{array}{c}\text { Sport } \\
\text { management }\end{array}$ & 25 & 9.3 \\
\hline Total & & 270 & 100.0 \\
\hline
\end{tabular}

Table 2. Descriptive statistics of teachers' transformational and transactional leadership levels and organizational cynicism sub-dimensions

\begin{tabular}{cccc}
\hline Dimensions & $\mathbf{N}$ & $\overline{\mathbf{X}}$ & $\mathbf{S d}$ \\
\hline Cognitive Cynicism & 270 & 3,29 & 1.08 \\
\hline Emotional cynicism & 270 & 2,87 & 1.28 \\
\hline $\begin{array}{c}\text { Behavioural } \\
\text { cynicism }\end{array}$ & 270 & 3,38 & .92 \\
\hline $\begin{array}{c}\text { Organizational } \\
\text { cynicism general }\end{array}$ & 270 & 3.19 & .97 \\
\hline $\begin{array}{c}\text { Transformational } \\
\text { leadership }\end{array}$ & 270 & 3.71 & .55 \\
\hline $\begin{array}{c}\text { Transactional } \\
\text { leadership }\end{array}$ & 270 & 3.13 & .44 \\
\hline
\end{tabular}

As can be seen in Table 2, teachers' organizational cynicism score average was found as $(X=3.19)$. This means a moderate level of organizational cynicism. In terms of average scores of sub-dimensions, the highest average score was found in behavioural cynicism dimension $(X=3.38)$, while the lowest score was found in emotional cynicism dimension $(X=2.87)$. When the averages of transformational and transactional leadership dimensions were examined, teachers' transformational leadership 
perception averages $(X=3.71)$ were found to be higher than their transactional leadership average $(X=3.13)$.

Table 3. Transformational and transactional leadership and organizational cynicism sub-dimension t-test results of the participants in terms of their gender

\begin{tabular}{ccccc}
\hline Dimensions & $\begin{array}{c}\text { Male } \\
(\mathrm{n}=134)\end{array}$ & $\begin{array}{l}\text { Female } \\
(\mathrm{n}=136)\end{array}$ & $\mathrm{T}$ & $\mathrm{P}$ \\
\hline $\begin{array}{c}\mathbf{X} \\
\text { Cognitive cynicism }\end{array}$ & $3.33 \mp 1.06$ & $3.26 \mp 1.11$ & -.581 & .56 \\
$\begin{array}{c}\text { Affective cynicism } \\
\text { Behavioural } \\
\text { cynicism }\end{array}$ & $2.95 \mp 1.31$ & $2.80 \mp 1.17$ & -.937 & .34 \\
$\begin{array}{c}\text { Transformational } \\
\text { leadership } \\
\text { Transactional } \\
\text { leadership }\end{array}$ & $3.43 \mp .92$ & $3.34 \mp .93$ & -.771 & .44 \\
\hline$* \mathrm{p}<0.05$ & $3.22 \mp, 48$ & $3.04 \mp, 39$ & $-3,319$ & $.00^{*}$ \\
\hline
\end{tabular}

When Table 3 is examined, no significant difference was found between the averages of affective cynicism, affective cynicism, behavioural cynicism scores in terms of the gender variable $(p>0.05)$. However, significant difference was found between transformational leadership and transactional leadership styles in terms of gender. When the averages were examined, it was found that female teachers had higher transformational leadership perceptions than male teachers, while male teachers had higher transactional leadership perceptions than female teachers.

When Table 4.is examined, no statistically significant difference was found between the averages of affective cynicism, affective cynicism, behavioural cynicism scores in terms of the variable of school type $(p>0.05)$. No statistically significant difference was found between the averages of transformational leadership and transactional leadership styles in terms of the variable of type of school $(\mathrm{p}>0.05)$.

Table 4. Transformational and transactional leadership and organizational cynicism sub-dimension t-test results of the participants in terms of the type of school they worked in

\begin{tabular}{ccccc}
\hline Dimensions & $\begin{array}{c}\text { Secondary } \\
(\mathrm{N}=181)\end{array}$ & $\begin{array}{c}\text { High school } \\
(\mathrm{N}=89)\end{array}$ & $\mathrm{t}$ & $\mathrm{P}$ \\
\hline $\begin{array}{c}\text { Cognitive } \\
\text { cynicism } \\
\text { Affective } \\
\text { cynicism } \\
\text { Behavioural } \\
\text { cynicism }\end{array}$ & $3.20 \mp 1.10$ & $3.45 \mp 1.02$ & -1.749 & .08 \\
$\begin{array}{c}\text { Transformational } \\
\text { leadership }\end{array}$ & $3.77 \mp .92$ & $3.40 \mp .93$ & -.211 & .83 \\
$\begin{array}{c}\text { Transactional } \\
\text { leadership }\end{array}$ & $3.14 \mp, 44$ & $3.11 \mp, 45$ & .476 & .63 \\
\hline $\mathrm{p}<0.05$ & & $3.72 \mp, 62$ & -.246 & .80 \\
\hline
\end{tabular}

When Table 5 is examined, teachers' cognitive cynicism $(\mathrm{F}=2.906 ; \mathrm{p}=0.05<0.05)$ and affective cynicism $(\mathrm{F}=5.807$; $\mathrm{p}=0,00<0.05$ ) average scores were found to be statistically significant in terms of the variable of gender. No significant difference was found between behavioural cynicism dimension and the variable of age $(F=2.789 ; p=0$, $06>0.05)$. Teachers' cognitive cynicism $(\mathrm{F}=15.83 ; \mathrm{p}=0$, $00<0.05)$, affective cynicism $(\mathrm{F}=35.93 ; \mathrm{p}=0,00<0.05)$ and behavioural cynicism $(\mathrm{F}=10.91 ; \mathrm{p}=0,00<0.05)$ average scores were found to be statistically significant in terms of the variable of professional seniority. Teachers' cognitive cynicism $(\mathrm{F}=1.016 ; \mathrm{p}=0,36>0.05)$, affective cynicism $(\mathrm{F}=1.291 ; \mathrm{p}=0,27>0.05)$ and behavioural cynicism $(\mathrm{F}=.286 ; \mathrm{p}=0.75>0.05)$ average scores were not found to be statistically significant in terms of the variable of department graduated.

Table 5. Anova-Test results of participants' organizational cynicism sub-dimensions in terms of the variables of age, Professional seniority and the department graduated

\begin{tabular}{|c|c|c|c|c|c|c|c|c|c|c|c|c|c|}
\hline \multirow[b]{2}{*}{ Age } & \multicolumn{2}{|c|}{ Cognitive } & \multicolumn{3}{|c|}{ Affective } & \multicolumn{5}{|c|}{ Behavioural } & \multirow[b]{2}{*}{$\mathrm{Sd}$} & \multirow[b]{2}{*}{$\mathrm{F}$} & \multirow[b]{2}{*}{$\mathrm{P}$} \\
\hline & $\mathrm{N}$ & $X$ & $\mathrm{Sd}$ & $\mathrm{F}$ & $\mathrm{P}$ & $\mathrm{X}$ & $\mathrm{Sd}$ & $\mathrm{F}$ & $\mathrm{P}$ & $\mathrm{X}$ & & & \\
\hline $21-25$ & 41 & 3.18 & .87 & & & 2.62 & 1.03 & & & 3.19 & .87 & & \\
\hline $26-30$ & 78 & 3.09 & 1.10 & 2.906 & $.05^{*}$ & 2.56 & 1.17 & 5.807 & $.00 *$ & 3.26 & .96 & 2.789 & .06 \\
\hline 31 and older & 151 & 3.43 & 1.11 & & & 3.11 & 1.35 & & & 3.50 & .91 & & \\
\hline \multicolumn{14}{|c|}{ Professional seniority } \\
\hline 1-5 Years & 154 & 3.14 & 1.07 & & & 2.58 & 1.14 & & & 3.24 & .94 & & \\
\hline 6-10 Years & 66 & 3.10 & 1.13 & 15.83 & $.00^{*}$ & 2.64 & 1.33 & 35.93 & $.00^{*}$ & 3.31 & .93 & 10.91 & $.00^{*}$ \\
\hline 11 and higher & 50 & 4.04 & .69 & & & 4.11 & .80 & & & 3.92 & .64 & & \\
\hline \multicolumn{14}{|c|}{ Department graduated } \\
\hline Teaching & 169 & 3,36 & 1,01 & 1.016 & .36 & 2,97 & 1,28 & 1.291 & .27 & 3,36 & .91 & & \\
\hline Coaching & 76 & 3,15 & 1,22 & & & 2,72 & 1,31 & & & 3,45 &, 93 & .286 & .75 \\
\hline Management & 25 & 3,26 & 1,13 & & & 2,70 & 1,10 & & & 3,37 & 1,0 & & \\
\hline
\end{tabular}

$* \mathrm{p}<0.05$ 
Table 6. Anova-Test results of participants' transformational leadership and transactional leadership dimensions in terms of the variables of age, Professional seniority and the department graduated

\begin{tabular}{|c|c|c|c|c|c|c|c|c|c|}
\hline \multirow[b]{2}{*}{ Age } & \multicolumn{5}{|c|}{ Transformational leadership } & \multicolumn{4}{|c|}{ Transactional leadership } \\
\hline & $\mathbf{N}$ & $\mathbf{X}$ & sd & $\mathbf{F}$ & $\mathbf{P}$ & $\mathbf{X}$ & Sd & $\mathbf{F}$ & $\mathbf{P}$ \\
\hline $21-25$ & 41 & 3.68 & .59 & & & 3.07 & .36 & & \\
\hline $26-30$ & 78 & 373 & 50 & .107 & .89 & 3.14 & .44 & .457 & .63 \\
\hline 31 and older & 151 & 3.71 & 57 & & & 3.15 & .47 & & \\
\hline \multicolumn{10}{|c|}{ Professional seniority } \\
\hline $1-5$ Years & 154 & 3.69 & .53 & & & 3.12 & .44 & & \\
\hline 6-10 Years & 66 & 3.82 & .49 & 2.218 & .11 & 3.16 & .46 & .163 & .85 \\
\hline 11 and higher & 50 & 3.61 & .68 & & & 3.12 &. .46 & & \\
\hline \multicolumn{10}{|c|}{ Department graduated } \\
\hline Teaching & 169 & 3.68 & .54 & & & 3.12 & .44 & & \\
\hline Coaching & 76 & 3.74 & .58 & .537 & .58 & 3.15 & .47 & .092 & .91 \\
\hline Management & 25 & 3.79 & .55 & & & 3.12 & .37 & & \\
\hline
\end{tabular}

$* \mathrm{p}<0.05$

According to the table 6 , no statistically significant difference was found between the transformational and transactional leadership perceptions of teachers in terms of the variables of age, professional seniority and the department graduated $(p>0.05)$.

\section{Discussion}

This study examines the transformational and transactional leadership perceptions and organizational cynicism perceptions of physical education teachers. The findings of this study show that teachers participating in the research perceive their school principals as transformational leaders $(X=3.71)$ and exhibit moderate $(X=3.19)$ cynic behavior.

The first sub-problem of the study was "What are the perceptions of teachers towards school directors' leadership styles?" When the findings were examined: Physical education teachers perceived their managers as transformational can be assessed as an indicator of behaviours such as those managers show extra efforts in sportive needs. The fact that school principals showing transformational leadership behaviors can help working staff to show positive attitudes and behaviors towards the school $[46,58]$. When this result is analyzed in terms of Turkish educational institutions, it can be interpreted as a positive result. These results show similarities with the study results of Baloğlu et al. [59]; Taş, et al. [60] It was found that school managers showed transformational leadership styles.

In parallel with this result, Öztop's [16] study showed that transformational leadership had strong influences on motivation, satisfaction and performance According to Şirin \& Yetim [61] study entitled "examination of transformational and transactional leadership styles of managers of school of physical education and sport", it was found that school managers showed first transformational and then transactional leadership styles In their study they examined the association between school directors' leadership styles and organizational cynicism according to the perceptions of secondary school teachers, Korkmaz ve Demirçelik [62] found that most of the school directors showed transformational leadership behaviours. Gövez [63] found that transformational and transactional leadership decreased the level of cynicism, while transformational leadership model affected (decreased) cynicism level more. In their study on the effect of school managers' leadership styles on exhaustion, Bakan [64] concluded that school managers showed laissez-faire leadership style the most, followed by transactional and transformational leadership behaviours.

The second sub-problem of the study was "What is the level of teachers' organizational cynicism perceptions?" When the findings were examined; the opinions of physical education teachers on organizational cynicism is within the "partly agree" interval according to the score intervals used in the assessment. According to this result, it was concluded that teachers had moderate levels of organizational cynicism.

In their studies, Balay et al. [65]; Mete \& Serin [66]; Nartgün ve Kartal [67]; Akduman ve Ölmez [68] concluded that teachers had moderate levels of organizational cynicism. The results of these studies are in parallel with the results of our study. According to the result of the study, teachers' have the highest point in behavioural dimension more than emotional and cognitive dimensions. These results show similarities with the study results of Ayık [69]; Erdoğdu [70]; Polat [71].

Considering that cynicism is something undesired in organizations, it can be concluded that teachers' having moderate level of cynicism attitude can mean that there is a problem in their institution and that the teachers are not comfortable about this. This reflected teachers' beliefs 
about the discrepancies between what the school says and does inconsistencies between practices and deeds, and teachers' doubts about implementations in the school. In the research conducted by Erdoğdu [70], it is aimed to examine the effect of organizational justice behaviours on organizational silence and cynicism regarding the opinions of academics serving at Schools of Physical Education and Sports and Faculties of Sports Sciences. The research showed that sub-dimensions of organizational cynicism are at low levels.

The third sub-problem of the study was "Are there differences between teachers' transformational and transactional leadership perceptions and their demographic characteristics?" No significant difference was found between the type of school teachers worked in, the department they graduated from and transformational and transactional leadership styles. Also, in Çakır [72]'s study, no significant difference was found between teachers' leadership styles and the level of school they worked in. This result shows that teachers' leadership style perceptions are not influenced by the level of school they worked in. No statistically significant difference was found between the transformational and transactional leadership perceptions of teachers in terms of the variables of age, professional seniority and the department graduated.

Teachers' transformational and transactional leadership levels' not being influenced by most of the demographic variables is in fact a result that can be wished by all managers because teachers' viewing their managers as a transformational leader, irrespective of age, professional seniority, and the department graduated from can be a desired result.

As another result of the study, difference was found between leadership attitudes and the variable of gender. Transformational leadership attitudes of female teachers were found to be higher than those of male teachers and it can be said that managers provide female teachers participation in the process and practices as much as they do to male teachers. Morçin [73] found significant difference between employees' transformational leadership perceptions and the variable of gender. These results are in parallel with the results of our study.

The fourth sub-problem of the study was "Are there differences between teachers' organizational cynicism perceptions and their demographic characteristics?" No significant difference was found between gender and organizational cynicism sub-dimensions. In their studies, Helvacı and Çetin [43]; Güçlü [74]; Efilti et al. [75]; Erdost et al. [76]; Güzeller and Kalağan, [77]; Bommer et al. [78] concluded that organizational cynicism perceptions did not show a significant difference in terms of gender.

In addition, it was reported in Kalağan and Güzeller's [42] study that there was no significant association between teachers' gender and organizational cynicism levels. Teachers' gender does not influence their organizational cynicism levels. The reason for this can be explained with the fact that in teaching profession, professional roles do not differ according to gender. No significant difference was found between the type of school teachers worked in, the department they graduated from and organizational cynicism sub-dimension. In their studies, Kalağan and Güzeller [42] and Demirel [79] did not find a significant association between organizational cynicism and teachers' ages. This result is in parallel with the results of our study. In addition, Güllü and Arslan [80] reported that there were no significant differences between leadership styles in terms of the levels of schools physical education teachers worked in. Significant difference was found between teachers' professional seniority variable and cognitive dimension, affective dimension and behavioural dimension. When the literature is reviewed, it can be seen that Kalağan and Güzeller [42] also found a significant association between organizational cynicism and teachers' professional seniority. In Güçlü, Kalkan and Dağlı'nın [74]'s study entitled "The association between organizational cynicism and leadership styles of school directors according to vocational and technical secondary school teachers", significant difference was found in terms of teachers' professional seniority and changes in seniority. The reason for this is the fact that a teacher who has just started teaching or who is in the first years of teaching has a strong belief that he/she can more easily make changes and innovations in the institution he/she is working. However, despite these existing thoughts, it can be thought that he/she can start showing negative attitudes towards the organization as he/she starts to get acquainted with the policies, functioning and applications of the institution and his/her organizational cynicism level can increase. Demirel [79] did not find any significant association between teachers' organizational cynicism attitudes and their professional seniority. This result is not in parallel with our results. When school directors cannot show their transformational leadership characteristic effectively in favour of their employees, it is inevitable for organizational cynicism to emerge within the organization. For this reason, it can be thought that this variable will have a critical significance for educational institutions. It is thought that the study will give a guiding perspective in terms of showing managers' positive leadership behaviours, eliminating cynicism and showing which leadership behaviours should be adapted.

\section{Conclusions and Recommendations}

This study was conducted to examine physical education and sport teachers' transformational and transactional leadership and organizational cynicism perceptions. For this purpose, measuring transformational and transactional leadership and organizational cynicism perceptions could be an important aspect in identifying a school's capacity to implement a school-based intervention. The results of the 
study showed that physical education teachers had higher transformational leadership perceptions than transactional leadership and they had moderate levels of organizational cynicism. While there were no significant differences between the variables of teachers' genders, types of schools they worked in, their ages and the department they graduated from and the sub-dimensions of organizational cynicism and transformational and transactional leadership styles, significant difference was found between teachers' professional seniority and cognitive dimension, affective dimension and behavioural dimension.

According to these results, physical education teachers can be trained about showing more democratic attitudes and behaviours during their undergraduate education.

In addition, teachers can be given in-service training to decrease the situations that cause cynicism and teachers' sense of belonging to school can be developed.

It can be recommended to conduct similar studies by collecting qualitative data collection methods and on teachers of different branches in terms of increasing teachers' performance and the quality of education. At the same time, it can be recommended to conduct qualitative studies in terms of making clearer explanations about what the basic dynamics of the presence of organizational cynicism.

\section{REFERENCES}

[1] Sinan, Y., \& Kavas, E. (2016). Organizational cynicismin organizations: A comparative analysis. The Journal of International Social Research, (9), 44.

[2] Arabac1, İ. B. (2010). The effects of depersonalization and organizational cynicism levels on the job satisfaction of educational inspectors. African Journal of Business Management, 4(13), 2802-811

[3] Gün, F., \& Atanur Baskan, G. (2017). Öğretim elemanlarinin algılarına göre örgütsel sinizm ile tükenmişlik düzeyleri arasindaki ilişkinin incelenmesi. Hacettepe Üniversitesi Eğitim Fakültesi Dergisi. 32(2), 361-379

[4] Ercan, Y. (2006). Okullardaki örgütsel güven düzeyinin bazi değişkenler açisindan incelenmesi. Selçuk Üniversitesi Sosyal Bilimler Enstitüsü Dergisi, 16, 739-756

[5] Avc1, A. (2015). Dönüşümcü ve işlemci liderlik stilleri: Kavramsal çerçevesi ve eğitim örgütleri açısından etkileri. İnsan ve Toplum Bilimleri Dergisi 5.

[6] Bilgiç, H.F. (2017). Liderlik ile örgütsel sinizm ilişkisi. Akdeniz Üniversitesi Sosyal Bilimler Enstitüsü Dergisi. Say1 2.

[7] Nourthouse, P. G. (2010). Leadership: Theory and practice. NY: Sage

[8] Vigoda-Gadot, E. (2006). Leadership style, organizational politics, and employee's performance: An empirical examination of two competing models. Personnel Review,
$36(5), 661-683$.

[9] Zel, U. (2006). Kişilik ve liderlik. Ankara: Nobel Yayınevi

[10] Bakan, İ., Büyükbeşe, T., \& Bedestenci, H.Ç. (2004). Organizational culture in the solution of organizational secrets theoretical and empirical approach, Actual Publications, 5, 58.İstanbul, Turkey

[11] Ogbonna, E., \& Harris, L.C. (2000). Organizational culture and performance: empirical evidence from UK companies, International Journal of Human Resource Management,11, 4,766-788

[12] Bass, B.M., Avolio, B.J., Jung, D.I., \& Berson, Y. (2003). Predicting unit performance by assessing transformational and transactional leadership. Journal of Applied Psychology. 88(2), 207-218.

[13] Yukl, G. (1989). Managerial leadership: A review of theory and research. Journal of Management, 15(2), 251-289.

[14] Koh, W. L., Steers, R. M. \& Terborg, J. R. (1995). The effects of transformational leadership on teacher attitudes and student performance in Singapore. Journal of Organizational Behavior, 16, 319-333.

[15] Çetin, Ş., Korkmaz, M. \& Çakmakçı, C. (2012). Dönüşümsel ve etkileşimsel liderlik ile lider-üye etkileşiminin öğretmenlerin örgütsel vatandaşlık davranışı üzerindeki etkisi. Kuram ve Uygulamada Eğitim Yönetimi. 7-36.

[16] Öztop, İ. (2008). Liderlik tarzları ve örgüt kültürü tipleri arasındaki ilişki ve bu ilişkinin nitel performans üzerine etkileri. Yüksek Lisans Tezi. Gebze.

[17] Bass, B., \& Riggio, R. E. (2006).Transformational leaderhip. New Jersey: Lawrence Erlbaum Associates.

[18] Kim, H. (2012). Transformational leadership and organisational citizenship behavior in the public sector in South Korea: The mediating role of affective commitment, Local Government Studies, 38, (6), 867-892.

[19] Hall, J., Johnson, S., Wysocki, A., \& Kepner, K. (2002). Transformational leadership: the transformation of managers and associates.

[20] Van Dierendonck, D. (2011). Servant leadership: A review and synthesis. Journal of Management, 37(4), 1228-1261

[21] Konakl1, T. (2016). The Effect of School Administrators' Political Skills against Organizational Cynicism in Educational Organizations. Universal Journal of Educational Research, 4(3): 589-597

[22] Leithwood, K., \& Jantzi, D. (2006). Transformational school leadership for large-scale reform: Effects on students, teachers, and their classroom practices. School Effectiveness and School Improvement, 17(2), 201-227

[23] Midthassel, U. V., \& Ertesva, S. K. (2008). Schools implementing zero: The process of implementing an antibullying program in six Norwegian compulsory schools. Journal of Educational Change, 9, 153-172

[24] Omar, Z., Zainal, A., Omar, F., \& Khairudin, R. (2009). The influence of leadership behaviour on organisational citizenship behaviour in selfmanaged work teams in Malaysia. SA Journal of Human Resource Management. 
[25] Koh, W. L., Steers, R. M., \& Terborg, J. R. (1995). The effects of transformational leadership on teacher attitudes and student performance in Singapore. Journal of Organizational Behavior, 16, 319-333.

[26] Howell, J.M., \& Avolio, B.J. (1993). Transformational leadership, transactional leadership, locus of control, and support for innovation: Key predictors of consolidated-business-unit performance. Journal of Applied Psychology, 78 (6).

[27] Morçin, E.S. (2013).The effect of transactıonal leadership upon organizational citizenshıp behavior: A case of travel agencies in Adana.The Journal of Visionary, 4 (9), 70-80.

[28] Howell, J.M., \& Avolio, B. J. (1993).Transformational leadership, transactional leadership, locus of control, and support for innovation: Key predictors of consolidated business-unit performance. Journal of Applied Psychology,78,891-902

[29] Bass, B.M., \& Avolio, B.J. (2000). MLQ: Multifactor leadership questionnaire. Redwood City, CA: Mind Garden.

[30] Hsu C-C., Chen L., Hu Y-W., Yip W., \& Shu C-C. (2006). the dimensions of responsiveness of a health system: a Taiwanese perspective. BMC Public Health 6: 72

[31] Bowditch, J.L. \& Buono, A.F. (2001). A primes on organizational behaviour. (Fifth Edition) John Wiley \& Sons, New York

[32] Bakan, İ. (2008). Örgüt kültürü ve liderlik türelerine ilişkin algılamalar ile yöneticilerin demografik özellikleri arasındaki ilişki: Bir alan araştırması. KMU İİBF Dergisi

[33] James, M.S.L. (2005). Antecedents and consequences of cynicism in organizations: An examination of the potential positive and negative effects on school systems (Dissertation), The Florida State University

[34] Anderrson, L., \& Bateman, T. S. (1997). Cynicism in the work place: Some causes and effects. Journal of Organizational Behavior, 18, 449-470

[35] Tokgöz, N., \& Y1lmaz, H. (2008). Örgütsel sinisizm: Eskişehir ve Alanya'daki otel işletmelerinde bir uygulama. Anadolu Üniversitesi Sosyal Bilimler Dergisi, 8 (2), 283-305.

[36] Abraham, R. (2000). Organizational cynicism: Bases and consequences, genetic, social and general psychology monographs, Vol: 126 (3), 269- 292.

[37] Karacaoğlu, K., \& İnce, F. (2013). Pozitif örgütsel davranışın örgütsel sinizm üzerindeki etkileri: Kayseri ilindeki imalat sanayi işletmelerinde bir uygulama. Süleyman Demirel Üniversitesi İktisadi ve İdari Bilimler Fakültesi Dergisi, 18(1), 181-202

[38] Dean Jr, J.W., Brandes, P., \& Dharwadkar, R. (1998). Organizational Cynicism. The Academy of Management Review, 23 (2), 341-352

[39] Delken, M. (2004). Organizational cynicism: A study among call centers. Unpublished Master Thesis, University of Maastricht, Faculty of Economics and Business Administration, Maastricht.

[40] Cartwright, S., \& Holmes, N. (2006). The meaning of work:
The challenge of regaining employee engagement and reducing cynicism. Human Resources Management Review, 16,199-208.

[41] Kanter, D.L., \& Mirvis, P.H. (1989). The cynical Americans. San Francisco: Jossey-Bass.

[42] Kalağan, G., \& Güzeller, C.O. (2010). Öğretmenlerin örgütsel sinizm düzeylerinin incelenmesi. Pamukkale Üniversitesi Eğitim Fakültesi Dergisi, 27, 83-97.

[43] Helvacı, M. A., \& Çetin, A. (2012). İlköğretim okullarında görev yapan öğretmenlerin örgütsel sinizm düzeylerinin belirlenmesi (Uşak ili örneği). International Periodical For The Languages, Literature and History of Turkish or Turkic, 7(3), 1475-1497

[44] Evans, W. R., Goodman, J. M., \& Davis, W.D. (2011). The impact of perceived corporate citizenship on organizational cynicism, OCB, and employee deviance. Human Performance, 24 (1), 79-97

[45] Stanley, D., Meyer, J., \& Topolnytsky, L. (2005). Employee cynicism and resistance to organizational change. Journal of Business and Psychology, 19, (4), 429-459

[46] Neves, P. (2012). Organizational cynicism: Spillover effects on supervisor- subordinate relationships and performance. The Leadership Quarterly, 23(5), 965-976

[47] Peng, Z., \& Zhou, F. (2009). The moderating effect of supervisory conscientiousness on the relationship between employee's social cynicism and perceived interpersonal justice. Social Behavior and Personality, 37(6), 863-864

[48] Karadağ, E., K1lıçoğlu, G., \& Y1lmaz, D. (2014). Örgütsel sinizm, okul kültürü ve okul başarısı: Bir yapısal eşitlik modelleme çalışması. Kuram ve Uygulamada Eğitim Bilimleri, 14 (1), 89-113

[49] Chiaburu, D.S., Peng, A.C., Oh, I. S., Banks, G. C., \& Lomeli, L. C. (2013). Antecedents and consequences of employee organizational cynicism: A meta-analysis. Journal of Vocational Behavior, 83 (2), 181-197

[50] Demirçelik, E., \& Korkmaz, M. (2017). The relationship between the leadership styles of school managers and organizational cynicism according to the perceptions of secondary school teachers, International Journal of Society Researches, 7(12), 33-53

[51] Özler, D. E., Atalay, C. G., \& Şahin, M. D. (2010). Örgütlerde sinizm güvensizlikle mi bulaşır? Organizasyon ve Yönetim Bilimleri Dergisi. 2(2), 47-57.

[52] Nguyen, T. H. N. (2013). Examining multiple leadership styles and their influences on employee outcomes in the Auckland workplace: A mediation study (Unpublished master's thesis). Massey University, Wellington, New Zealand.

[53] Gkorezis, P., Petridou, E., \& Krouklidou, T. (2015). The detrimental effect of machiavellian leadership on employees' emotional exhaustion: Organizational cynicism as a mediator. Europe's Journal of Psychology, 11(4), 619-631

[54] Doğan S. \& Uğurlu C. (2014). Okul yöneticilerinin etik liderlik davranişlari ile öğretmenlerin örgütsel sinizm algilari arasindaki ilişki. Gazi Üniversitesi Gazi Eğitim Fakültesi Dergisi, 34(3), 489-516 
[55] Dean, J. W. Jr., Brandes, P., \& Dharwadkar, R. (1998). Organizational Cynicism. The Academy of Management Review. 23 (2), 341-352

[56] Kalağan, G. (2009). Araștırma görevlilerinin örgütsel destek algıları ile örgütsel sinizm tutumları arasındaki ilişki. Yüksek Lisans Tezi, Akdeniz Üniversitesi Sosyal Bilimler Enstitüsü, Antalya

[57] Bass, B.M., \& Avolio, B.J. (2000). MLQ: Multifactor leadership questionnaire. Redwood City, CA: Mind Garden

[58] Jung, D. I., Chow, C., \& Wu, A. (2003). The role transformational leadership in enhancing organizational innovation: Hypotheses and some preliminary findings. The Leadership Quarterly, 14, 525-544

[59] Baloğlu, N., Karadağ, E. \& Gavuz, Ş. (2009). İlköğretim Okulu Müdürlerinin Çok Faktörlü Liderlik Stillerinin Yetki Devri Düzeylerine Etkisi: Bir Doğrusal ve Yapısal Eşitlik Modelleme Çalışması, Uludağ Üniversitesi Eğitim Fakültesi Dergisi, 22(2): 457-479

[60] Taş, A., Çelik, K. \& Tomul E. (2007). Yenilenen İlköğretim Programının Uygulandığı İlköğretim Okullarındaki Yöneticilerin Liderlik Tarzları, Pamukkale Üniversitesi Eğitim Fakültesi Dergisi, 2(22): 85-98.

[61] Şirin, E.F., Yetim A. (2008). Beden eğîtîmî ve spor yüksekokulu yöneticilerinin dönüşümcü ve etkileşimci liderlik stillerinin incelenmesi. Gazi Üniversitesi Beden Eğitimi ve Spor Bilimleri Dergisi, XIII 4: 31 - 46.

[62] Korkmaz, M., \& Demirçelik, E. (2015). Ortaokul öğretmenlerinin algılarına göre okul yöneticilerinin liderlik stilleri ile örgütsel sinizm arasındaki ilişki. 10. Ulusal Eğitim Yönetim Kongresinde, Gaziantep.

[63] Gövez, E. (2013). Örgütsel sinizm ve dönüştürücü/etkileşimci liderlik arasındaki ilișki. Yayınlanmamış Yüksek Lisans Tezi, Atatürk Üniversitesi Sosyal Bilimler Enstitüsü, Erzurum

[64] Bakan, İ., Erşahan, B., Büyükbeşe, T., Doğan, İ.F., \& Kefe, İ. (2015). Dönüşümcü ve etkileşimci liderlik ile öğretmenlerin tükenmişlik düzeyleri arasındaki ilişki. Uluslararası İktisadi ve İdari İncelemeler Dergisi. 7(14), ISSN 1307-9832.

[65] Balay, R., Kaya, A., \& Cülha, A. (2013). Örgüt kültürü ve örgütsel sinizm ilişkisi. Cumhuriyet Üniversitesi. İktisadi ve İdari Bilimler Dergisi, 14(2).

[66] Mete, Y. A., \& Serin, H. (2015). Okul yöneticilerinin babacan liderlik davranışı ile öğretmenlerin örgütsel vatandaşlık ve örgütsel sinizm davranışları arasındaki ilișki. Hasan Ẩli Yücel Eğitim Fakültesi Dergisi, 12(2), 147-159.

[67] Nartgün, S.S., \& Kartal, V. (2013). Öğretmenlerin örgütsel sinizm ve örgütsel sessizlik hakkındaki görüşleri. Bartın Üniversitesi Ĕgitim Fakültesi Dergisi, 2(2), 47-67

[68] Akduman-Yetim, S., \& Ölmez-Ceylan, Ö. (2011). Örgütsel sinizm ve örgütsel vatandaşlık davranışları arasındaki ilişkiyi belirlemeye ilişkin bir araștırma. E-Journal of New World Sciences Academy Education Sciences, 6, (1), 682-
695.

[69] Ayık, A. (2015). An analysis of the relationship between organizational communication and organizational cynicism according to teachers' perceptions in Turkey. Educational Research and Reviews.10(5), 547-555

[70] Erdoğdu, M. (2018). Effect of organizational justice behaviors on organizational silence and cynicism: A research on academics from schools of physical education and sports. Universal Journal of Educational Research 6(4): 733-741.

[71] Polat S. (2013). The impact of teachers' organizational trust perceptions on organizational cynicism perception. Educational Research and Reviews. 8(16), 1483-1488

[72] Çakır, M (2015). “Öğretmenlerin liderlik stilleri ile sınıf içi öğretmen davranışları arasındaki ilişkinin incelenmesi”. Yayınlanmamış Yüksek Lisans Tezi. Abant İzzet Baysal Üniversitesi Bolu.

[73] Erdoğan-Morçin, S., \& Bilgin, N. (2014). Dönüştürücü liderliğin örgütsel bağliliğa etkisi: Adana ilindeki a grubu seyahat acenteleri örneği. Ç. Ü. Sosyal Bilimler Enstitüsü Dergisi, 23(2), 113-128.

[74] Güçlü, N., Kalkan, F., \& Dağlı, E. (2017). Mesleki ve teknik ortaöğretim okulu öğretmenlerinin algılarına göre okul müdürlerinin liderlik stilleri ile örgütsel sinizm arasındaki ilişki. Gazi Üniversitesi Eğitim Fakültesi Dergisi. 37(1), 177-192

[75] Efilti, S., Gönen, Y. \& Öztürk, F., (2008). Organizational cynicism: A field research on executive secretaries working at Akdeniz University. 7th National Congress of Office Management and Secretarial, Trabzon: Karadeniz Technical University,1-14

[76] Erdost, H.E., Karacaoğlu, K. \& Reyhanoğlu, M., (2007). The testing of scales on organizational cynicism at a company in Turkey. 15th Proceedings of the National Management and Organization Congress, Sakarya University, 514-524

[77] Güzeller, C.O. \& Kalağan, G., (2008). Turkish adaptation of the scale of organizational cynicism and its examination in educational organizations in terms of various variables. 16th Management and Organization Congress, Istanbul Kultur University, Antalya, 87-94

[78] Bommer, W.H., Rich, G.A. \& Rubin, R.S., (2007). Changing attitudes about change: longitudinal effects of transformational leader behavior on employee cynicism about organizational change. The Journal of Organizational Behavior, 26, 733-753

[79] Demirel, N. (2015). Öğretmen algılarına göre okul müdürlerinin toksik liderlik davranışları ile öğretmenlerin örgütsel sinizm tutumları arasındaki ilişki. (Gaziantep Şehitkamil ilçesi örneği). Yüksek Lisans Tezi. Kahramanmaraş.

[80] Güllü, M., \& Arslan, C. (2009). Beden eğitimiöğretmenleri nin liderlik stilleri. Mustafa Kemal Üniversitesi Sosyal Bilimler Enstitüsü Dergisi, 11,353-368. 